\title{
Investigating the Problems of Teaching Online by In- service Teachers During COVID-19 Pandemic
}

\author{
Maryani $^{1^{*}}$, Fatchul Mu'in ${ }^{2}$, Nasrullah $^{3}$, Elvina Arapah $^{4}$, Emma Rosana Febriyanti $^{5}$ \\ 1, 2, 3, 4, 5 Universitas Lambung Mangkurat \\ "Corresponding author. Email: aniemaryanii@gmail.com
}

\begin{abstract}
The invasion of the COVID-19 virus in Indonesia has sent in-service teachers and students to shift traditional teaching into online learning. However, the unpreparedness of the practice of online learning gives rise to problems in its implementation. Despite plenty of similar studies focusing on online learning, they still lack of vivid explanations about the problems that appeared during online learning, especially in in-service teachers' problems and perspectives. Due to the current condition, this research was conducted to find out the problems faced by the English in-service teachers during the implementation of online learning. Therefore, this study is aimed at portraying the problems that hinder online learning from in-service teachers' perspectives. The researchers used a qualitative approach with the interview and questionnaire as the tools to collect the data. The result shows that the English in-service teachers had several problems during the implementation of online learning. These are (1) problems in the process of online English language teaching, (2) problems in using application and software, and (3) problems from the students that have mainly become the main problems in implementing online learning during COVID-19 pandemic time.
\end{abstract}

Keywords: COVID-19 pandemic, online learning, teaching problems.

\section{INTRODUCTION}

The term of online learning has brought to the educational world by the University of Toronto since 1984. Many educational institutions in Indonesia have turned their traditional learning into online learning due to the COVID-19 pandemic. It is highly recommended that people stay and work from home to prevent the spread of the COVID-19 virus [22, 28]. Moreover, this method is considered the most effective method as one of the characteristics of online learning is distance learning [14]. Online learning, however, shares the same attributes as traditional education, where the teaching emphasizes the concept of "any time-any place" [18].

In the application of online learning, ICT (information and communication technology) skills are required to for both in-service teachers and students. Furthermore, online learning demands in-service teachers to be creative in delivering the lesson by designing an attractive multimedia content $[12,14,23$, 27].

As the challenges of online learning, in Indonesia, about $60 \%$ of in-service teachers are incompetent in using ICT caused by different abilities in mastering ICT
[13]. In this case, the failure on utilizing the technology in real life became one of the factors which affecting the in-service teachers' competency on implementing online learning [19]. On the other hand, since online learning requires internet, there is only about $68 \%$ of Indonesian students have the accessibility to internet network.

According to the background of the study, the research problem in this study is what are the problems in the teaching and learning process faced by the English in-service teachers of MAN 4 Banjar during the application of online learning in the COVID-19 pandemic situation. In addition, this study is aimed at finding out the problems in the teaching and learning process while applying online learning faced by the English in-service teachers of MAN 4 Banjar during the COVID-19 pandemic.

\section{LITERATURE REVIEW}

\subsection{Online Learning}

Online learning is a type of distance learning and it is not attended at school. Online learning includes the 
worldwide web (WWW), email, chat, new groups and texts, audio and video conferencing through the internet to impart education [7]. Regarding its engagement in education, online learning is classified into two types: computer-based online learning and internet-based online learning. Moreover, in the application of online learning, there was found several problems caused by lack of careful planning and implementation [7], there are:

\section{Poor Communication}

Because of its indirect learning style, online learning might cause misunderstandings between in-service teachers and students. It also affected the bonding between in-service teachers and students.

\section{Feeling Isolated}

Students' social development is lower due to less interaction with real people in the application of online learning. In addition, feeling isolated is one of the stress factors which affect students' mentality when meeting new people.

\section{Lack of Motivation}

The distractions from other things and activities during online learning might lower students' motivation to study.

\section{Lack of Funds}

Technology used in online learning, including cost, hardware and internet problems, production of course materials, and funds availability [7].

\section{Lack of Quality}

Incompetent online instructors affected the quality of online learning. They are commonly less committed to the lesson.

\section{Poor Accessibility in Remote Area}

The students who live in a remote area with limited access to the internet, along with the availability of hardware and software, are left behind rather than their peers who live around a city or town.

\subsection{Teaching Problems}

Several problems appeared during the application of online learning. The problems faced by the in-service teachers during the implementation of the method make the teaching process slower and weaker [2]. Furthermore, the problems in teaching online are correlated to developed technology [6], for example, downloading and installation issues, account login problems, and audio-video problems. In this case, the key challenges faced by English in-service teachers in applying online learning are mentioned below [11]:

1. Limited Accessibility and Network Connection
Accessibility problems in the application of online learning are mentioned as poor quality hardware, out-ofdate software, and lack of personal access for the inservice teachers to use an active computer $[4,11]$.

\section{School with Limited Technical Support}

Limited technical support has been one of the problems in the use of ICT in the educational field [21]. Furthermore, disconnected from the internet, timewasting for waiting for the website to open, printer's problems, and malfunctioning computers are also become the technical problems which appear during the online teaching and learning process.

\section{Lack of Effective Training}

The lack of effective training is quite complex because some aspects ensure training effectiveness [4]. There is time for training, pedagogical training, skills training, and ICT use in initial teacher training.

\section{Limited Time}

Online learning has a short and limited duration. Because of that, the in-service teachers need to have good time management in reaching and achieving the learning objectives [11].

\section{Lack of In-service teachers' Competency}

In several previous studies, it found that in-service teachers are still lacking in integrating ICT for their class, lack the knowledge and skill to use a computer, and feeling unenthusiastic about applying online learning into their teaching practices [11].

\subsection{COVID-19 Pandemic}

Novel Coronavirus Disease (COVID-19 virus) is a new kind of coronavirus categorized as an infectious virus. The outbreak started in Wuhan, Hubei Province in China, and this virus is currently spread rapidly through individual contact and has infected more than 200 countries worldwide. This virus brings respiratory problems to its patient and has similar symptoms to common flu and pneumonia, such as fever, cough, dyspnea, headache, sore throat, and rhinorrhea [10].

Due to pandemic situations and dangerous infectious virus, WHO (World Health Organization) and European Centre for Disease Prevention and Control in 2020 recommend people to stay at home and start working from home, applied to any field of social life. In addition, physical distancing and infection prevention guides have been declared for individual-level and multiple people.

Regarding the physical distancing, European Centre for Disease Prevention and Control (2020) suggested the related parties (1) isolate COVID-19 patients and people with respiratory symptoms, quarantine their contacts, (2) instigate to stay at home for people with a 
high risk of severe disease, (3) close educational institutions, and workplaces, (4) make limitation of visitors, physical contact, mass gathering, and small meeting, (5) determine mandatory quarantine of all inhabitants of buildings or residential areas, (6) conduct internal or external border closure and (7) make a stay at home restrictions for entire regions or countries [5].

Furthermore, European Centre for Disease Prevention and Control (2020) proposed three solutions to mitigate the impact of the COVID-19 virus for nonpharmaceutical activities. There are (1) washing hands in running water with soap and using alcohol-based hand sanitizer, (2) covering the mouth when sneezing or coughing to block virus droplets transmission, and (3) using a surgical face mask for the person who has respiratory problems and fabric face mask for people who are in good health [5].

\section{METHOD}

\subsection{Design}

This research used a descriptive method to describe and explain the findings on the problems faced by English in-service teachers of MAN 4 Banjar in applying online learning in the COVID-19 Pandemic. The researchers employed a qualitative approach because the data of this research is mostly in the form of words.

\subsection{Participants}

This research was conducted in MAN 4 Banjar, Jl. Pendidikan No. 1, Sekumpul, Kec. Martapura, Banjar, Kalimantan Selatan, 70614. The English in-service teachers who used and actively taught via online learning were recruited as the participants of this research.

\subsection{Instruments}

Interviews and close-ended questionnaires were used as the instruments of this research. The interview was used as the main technique where the researchers gathered the data about the problems in applying online learning during the COVID-19 Pandemic. On the other hand, the close-ended questionnaire is used to detect the English in-service teachers' attitudes towards the application of online learning. The instrument is then used to get deeper information about problems in applying online learning.

\subsection{Procedures}

1. The researcher distributed the close-ended questionnaire via Google Form from October, 6th 2020, until October, 10th 2020, to the English inservice teachers of MAN 4 Banjar. The English in- service teachers' answers to this close-ended questionnaire will show their perspective on online learning during the COVID-19 pandemic.

2. After collecting the close-ended questionnaire answers, the researcher then interviewed the English in-service teachers of MAN 4 Banjar to obtain detailed information about the problems in the implementation of online learning.

\section{RESULT AND DISCUSSION}

\subsection{Teaching Time and Duration during Online English Language Teaching}

According to the interview result, $\mathrm{H}$ and $\mathrm{F}$ mentioned in their interview that they doubt about achieving the learning objectives due to the current time allotment and new design of the lesson plan. This situation is mentioned in the interview:

\begin{abstract}
"Tidak yakin. Pembelajaran masa pandemi ini tidak menargetkan pencapaian kurikulum, jadi lebih diarahkan kepada pembentukan karakter dan literasi, yang penting semangat anak belajar itu masih ada, membangun kesadaran tentang kesehatan. (English version: I am not sure about it. The lesson during this pandemic is not aimed to the curriculum target, it is directed to character building and literacy skill, as long as the eagerness of students to learn is in a good condition, to build their awareness about health.)" (Participant H)

"... , tapi untuk sekarang tidak maksimal, tapi setidaknya apa yang kita harapkan minimal siswa mengerti apa yang disampaikan. (English version: ... it is not optimal, at least, we expect our students to understand what we have taught them.)" (Participant F)
\end{abstract}

Before online learning was started to be applied in MAN 4 Banjar, the English in-service teachers had around 2-4 hours of teaching duration for each class while in online learning they only have about 60 minutes to teach. For each day, AR, H, and BR explained the lesson started from 08.00 WITA until 13.00 WITA with 4 (four) different subjects for students to learn, including English that is scheduled only once a week. This was explained in the interview:

"Beda, kalau di pelajaran biasa, kita tatap muka di kelas itu 2 x 45 menit, totalnya 90 menit, sedangkan disini cuma 1 jam, 60 menit ... Kalau merekanya hadir ke sekolah, itu sampai jam 14.30 biasanya, kalau pada masa pandemi, masuk jam 08.00 berakhirnya jam 12.45 dan itu panjang waktunya. (English version: It is different. We usually have 2 x 45 minutes in offline class, 90 minutes in total, meanwhile we 
only have 1 hour, 60 minutes in online learning ... When the students come to school, the lesson end at 14.30 , but when it is on this pandemic times, the lesson start from 08.00 until 12.45 and the duration is quite long.)" (Participant AR)

\subsection{In-service Teachers' Proficiency in Online English Language Teaching}

As $\mathrm{AR}, \mathrm{H}$, and $\mathrm{BR}$ stated in the interview, the online learning process is fast and short. The lesson was

Table 1. Questionnaire Answers about Teaching Time and Duration during Online ELT

\begin{tabular}{|c|c|c|c|c|c|c|}
\hline \multirow{3}{*}{ Items } & \multirow{3}{*}{ Questions } & \multicolumn{5}{|c|}{ In-service Teachers' Responses } \\
\hline & & $\begin{array}{c}\text { Strongly } \\
\text { Agree }\end{array}$ & Agree & Neutral & Disagree & $\begin{array}{l}\text { Strongly } \\
\text { Disagree }\end{array}$ \\
\hline & & $\mathrm{N}$ & $\mathbf{N}$ & $\mathbf{N}$ & $\bar{N}$ & $\mathbf{N}$ \\
\hline 13 & $\begin{array}{l}\text { I am able to obtain the learning objectives } \\
\text { while teaching with online learning in the } \\
\text { current teaching duration. }\end{array}$ & $\begin{array}{c}1 \\
(20 \%)\end{array}$ & $\begin{array}{c}2 \\
(40 \%)\end{array}$ & $\begin{array}{c}2 \\
(40 \%)\end{array}$ & $(0 \%)$ & $(0 \%)$ \\
\hline 17 & $\begin{array}{l}\text { My teaching duration during the application } \\
\text { of online learning is around } 2-4 \text { hours per } \\
\text { class. }\end{array}$ & $(0 \%)$ & $\begin{array}{c}1 \\
(20 \%)\end{array}$ & $(0 \%)$ & $\begin{array}{c}4 \\
(80 \%)\end{array}$ & $\begin{array}{c}- \\
(0 \%)\end{array}$ \\
\hline 18 & $\begin{array}{l}\text { My teaching duration during the application } \\
\text { of online learning is fewer than } 2-4 \text { hours } \\
\text { per class. }\end{array}$ & $(0 \%)$ & $\begin{array}{c}4 \\
(80 \%)\end{array}$ & $\begin{array}{c}1 \\
(20 \%)\end{array}$ & $(0 \%)$ & $(0 \%)$ \\
\hline 19 & $\begin{array}{l}\text { My current teaching duration is as same as } \\
\text { my previous teaching duration before the } \\
\text { application of online learning. }\end{array}$ & $(0 \%)$ & $(0 \%)$ & $\begin{array}{c}1 \\
(20 \%)\end{array}$ & $\begin{array}{c}3 \\
(60 \%)\end{array}$ & $\begin{array}{c}1 \\
(20 \%)\end{array}$ \\
\hline 20 & $\begin{array}{l}\text { My teaching duration in a traditional class } \\
\text { is around } 2-4 \text { hours per class. }\end{array}$ & $(0 \%)$ & $\begin{array}{c}2 \\
(40 \%)\end{array}$ & $\begin{array}{c}1 \\
(20 \%)\end{array}$ & $\begin{array}{c}1 \\
(20 \%)\end{array}$ & $\begin{array}{c}1 \\
(20 \%)\end{array}$ \\
\hline
\end{tabular}

"Kalau pandemi cuma 1 jam saja, tapi kalau tidak pandemi 2 jam perminggu. Tapi 1 jam di pandemi itu 60 menit, tapi kalau tidak pandemi 2 jam nya itu $2 \times 45$ menit (90 menit). (English version: It is only an hour during this pandemic, when it is in a normal condition we have 2 hours per week. But, an hour in pandemic means 60 minutes, if it is not in pandemic we get 2 hours, 2 x 45 minutes (90 minutes).)" (Participant MZ)

"Komparasinya dengan saat kelas normal, misalnya bahasa Inggris itu ada 3 jam tatap muka jam 1-2-3, kalau masa pandemi itu dipress jadi satu jam saja karena menyesuaikan mata pelajaran lain, agar lebih optimal dan tidak membebani siswa. (English version: The comparison with normal, offline class, for example, English has 3 hours of schedule, 1-2-3, when it is in pandemic time, it is pressed to 1 hour to adjust with the object subjects, to optimize the lesson and not to burden the students.)" (Participant BR)

Furthermore, in the close-ended questionnaire, the results showed that the common teaching time and duration were enough for the English in-service teachers to deliver the lesson and to attain the learning objectives. opened by greeting the students, jumping to explain the materials. The lesson was closed right after the English in-service teachers finished their explanation and gave a daily assignment. This process includes waiting for students to join the class, which mostly becomes a waste.

“... kadang kita mau opening (ice breaking) susah karena waktu kita terbatas apalagi kita menunggu siswanya masuk semua, biasanya sampai 10 menit itu waktu kita menjelaskan sama mau penutup itu agak kepepet makanya langsung openingnya "Assalamualaikum”, tanya kabar, udah gitu aja, langsung ke materi, penutupnya, karena keterbatasan waktu tadi. (English version: ... when we are going to do an "ice-breaking", it is a bit difficult because we have a limited time, moreover, we need to wait for the students to come to the class, usually I only get 10 minutes to give the lesson and close the class it might be trapped, because of that the opening is just "Assalamualaikum", asking the students how are they doing lately, that is it, then jump to the explanation of the materials, and closing.)" (Participant AR)

In addition, it is found that the English in-service teachers adjusted their teaching materials into online materials to be sent to their students. The English inservice teachers mentioned that they used the various online materials during the application of online 
learning. These are group chatting, daily assessment in Google Form, video calls and conferences, pictures, videos, audio records, and self-made e-book.

It is mentioned that online learning is not recommended to be applied [1]. This is because online learning is just transferring the educational content, not teaching the lesson; in this case, the English in-service teachers hesitated about the effectiveness of online learning, as they mentioned in the interview. In addition, they admit that they faced several difficulties and problems during the application of online learning to their students in these outbreak times. It is also found by the Commissioner of KPAI about the problems of online learning that this method is not optimal since the majority of teachers in Indonesia rarely implement online learning before the COVID-19 Pandemic [12].

"Kalau efektif, ya nggak, kita interaksi kurang, terus minat siswa tidak sebesar dia masuk kelas, ketemu sama temen, interaksi langsung tatap muka sama gurunya, bisa canda langsung disitu, nggak, jadi kurang efektif sebenarnya. Tapi kalau bicara masalah pandemi, mau gak mau kita harus mau, jadi kembali ke kitanya sebagai guru, gimana caranya kita sebagai seorang guru supaya siswa tidak bosan. (English version: Talking about effectiveness, no it is not, we lack interaction, students' interest to learn is not as good as in offline class, as they meet their friends, direct face to face interaction with the teacher, have a chit chat and laugh, we cannot do that, it is not so effective. But when it comes to this pandemic, what can we do about this all, back to us as the teacher on how to make our students interested to learn and not getting bored with our current teaching.)" (Participant AR)

"... rasanya yang paling efektif itu ya online itu tadi. Karena, pertama, kita mencegah tertularnya virus COVID-19, rasanya online ini memang langkah terbaik. Ada pun yang lain itu ya kurang efektif karena kita belum bisa menyesuaikan diri dengan keadaan yang sekarang. (English version: ... online learning is the most effective method for this condition so far. Because, first, we prevent the transmission of the COVID-19 virus, I think online learning is the best solution. The other method probably ineffective because we still cannot fully adapt to the current situation.)" (Participant F)

"Kalau dikatakan efektif, mungkin masih belum. (English version: It is not so effective yet.)" (Participant BR)

"Sebenarnya untuk pembelajaran tidak efektif, karena yang namanya belajar itu bukan hanya membaca, dan menulis, mendengarkan dan sebagainya, tapi belajar itu lebih kepada sifat dan sikap siswa itu sendiri. Kalau ini kan kita hanya mengetahui hanya dari sisi pengetahuannya saja, sikap dan sifatnya kita nggak tau. (English version: It is not effective for learning, because learning is not only by reading, writing, listening, etc, but learning is more like the students' nature and attitude. If we know them only by their knowledge about something, we would not know how are their nature and attitude.)" (Participant MZ)

"Kalau dikatakan efektif, itu tidak efektif karena terbatas, terbatas waktu, karena siswa harus menghadapi 20 orang guru dengan 20 mata pelajaran yang berbeda. Segi efektifitasnya sangat berbeda dari pembelajaran tatap muka. (English version: This method is not effective because it is limited, limited on its teaching time, because the students need to meet 20 in-service teachers within 20 different subjects. Its effectiveness is much different than direct learning.)" (Participant H)

In this research, researcher found that the problems in applying online learning during COVID-19 pandemic are categorize into three, problems in online English language teaching, problems in using software and application, and problems from the students' side.

\subsubsection{Problems in Online English Language Teaching}

According to the answer of the interview, the English in-service teachers mentioned the problems they encountered were mostly related to student's behaviour during the lesson. The lack of feedback and students' evaluation was more intricate due to (1) indirect teaching style, (2) less interaction between teacher-tostudents and students-to-students interaction, and (3) the time wasted while waiting for the students to join the class are the problems that appeared during the online English language teaching. This finding supported by a study that mentioned online learning problems are related to the interaction between the in-service teachers and students, such as (1) limited interaction, (2) unable to explain detailed teaching materials, and (3) unable to control students' affective factors while the teaching and learning process [25].

Nevertheless, English in-service teachers' adaptability to the newest version of the lesson plan affected in-service teachers' proficiency in the application of online learning. This finding aligns with [24], in which old-aged in-service teachers are unfamiliar with current technology. It is influenced by the era when the in-service teachers were born. Today, most of the in-service teachers were born in 19th when there was no online learning conduct [25]. 


\subsubsection{Problems in Using Software and Application}

Improved technology, including the availability of the internet, gives better quality educational content to people [8]. WhatsApp, Google Meet, Zoom Cloud Meeting, Google Form, and school e-learning website are the application that the English in-service teachers used mostly during the application of online learning in MAN 4 Banjar.

In this case, the English in-service teachers found some troubles with the internet connection, errors, and incomplete application features while teaching. Moreover, the software and application features are also hindering the process of online English language teaching. These are, for example, (1) limited and one-
English in-service teachers of MAN 4 Banjar faced in the application of online learning.

\subsubsection{Problems from Students' Side}

Students mainly got problems with limited access to the internet connection. The students' residence affects the online teaching and learning process because (1) some of them live in a remote area, and (2) they probably have inadequate devices and ran out of internet data packages [29]. These are in line with the findings of this research where the students got the problems by the internet connection, where prohibit them to give a fast response to the in-service teachers, late on joining the class and collecting their assignment and disconnected from the class quite often.

Table 2. Questionnaire Answers about In-service Teachers' Proficiency in Online English Language Teaching

\begin{tabular}{|c|c|c|c|c|c|c|}
\hline \multirow{3}{*}{ Items } & \multirow{3}{*}{ Questions } & \multicolumn{5}{|c|}{ In-service Teachers' Responses } \\
\hline & & $\begin{array}{l}\text { Strongly } \\
\text { Agree }\end{array}$ & Agree & Neutral & Disagree & $\begin{array}{l}\text { Strongly } \\
\text { Disagree }\end{array}$ \\
\hline & & $\mathbf{N}$ & $\mathbf{N}$ & $\mathbf{N}$ & $\mathbf{N}$ & $\mathbf{N}$ \\
\hline 1 & $\begin{array}{l}\text { I am applying online learning during the } \\
\text { COVID-19 pandemic to my students. }\end{array}$ & $\begin{array}{c}3 \\
(60 \%)\end{array}$ & $\begin{array}{c}2 \\
(40 \%)\end{array}$ & $\begin{array}{c}- \\
(0 \%)\end{array}$ & $\begin{array}{c}- \\
(0 \%)\end{array}$ & $\begin{array}{c}- \\
(0 \%)\end{array}$ \\
\hline 6 & $\begin{array}{l}\text { I am able to apply online learning during } \\
\text { the COVID-19 pandemic. }\end{array}$ & $\begin{array}{c}4 \\
(80 \%)\end{array}$ & $\begin{array}{c}1 \\
(20 \%)\end{array}$ & $\begin{array}{c}- \\
(0 \%)\end{array}$ & $(0 \%)$ & $\begin{array}{c}- \\
(0 \%)\end{array}$ \\
\hline 10 & $\begin{array}{l}\text { I use online materials during teaching by } \\
\text { online learning in the COVID-19 pandemic. }\end{array}$ & $\begin{array}{c}3 \\
(60 \%)\end{array}$ & $\begin{array}{c}2 \\
(40 \%)\end{array}$ & $\begin{array}{c}- \\
(0 \%)\end{array}$ & $\begin{array}{c}- \\
(0 \%)\end{array}$ & $\begin{array}{c}- \\
(0 \%)\end{array}$ \\
\hline 12 & $\begin{array}{l}\text { I consider online learning is an effective } \\
\text { method to be applied during the COVID-19 } \\
\text { pandemic. }\end{array}$ & $\begin{array}{c}2 \\
(40 \%)\end{array}$ & $(0 \%)$ & $\begin{array}{c}3 \\
(60 \%)\end{array}$ & $(0 \%)$ & $\begin{array}{c}- \\
(0 \%)\end{array}$ \\
\hline 14 & $\begin{array}{l}\text { I meet several problems in applying online } \\
\text { learning. }\end{array}$ & $(0 \%)$ & $\begin{array}{c}5 \\
(100 \%)\end{array}$ & $(0 \%)$ & $(0 \%)$ & $(0 \%)$ \\
\hline
\end{tabular}

way interaction in WhatsApp, (2) manually accepting students' requests while having virtual class in Google Meet, (3) annoying pop-ups and limited time in using Zoom Cloud Meeting, and (4) errors when uploading lesson materials in school e-learning website. Furthermore, if the learning materials are less attractive, there will be a possibility of students who are not interested and fully understand the learning [23]. In addition, the English in-service teachers' proficiency in using software and application and interruption from other in-service teachers or students in school e-learning discussion sessions added to the problems that the
Moreover, in this pandemic situation, the English inservice teachers adapted well to the current lesson plans and new teaching methods by applying online learning. So it was shown in the questionnaire result:

\subsection{Accessibility Problems in Online English Language Teaching}

During the application of online learning, it was found that the school well facilitates the English inservice teachers of MAN 4 Banjar, and they own personal devices to teach their students. It is showed in the questionnaire result: 
Table 3. Questionnaire Answers about Accessibility Problems in Online English Language Teaching

\begin{tabular}{|c|c|c|c|c|c|c|}
\hline \multirow{3}{*}{ Items } & \multirow{3}{*}{ Questions } & \multicolumn{5}{|c|}{ In-service Teachers' Responses } \\
\hline & & $\begin{array}{l}\text { Strongly } \\
\text { Agree }\end{array}$ & Agree & Neutral & Disagree & $\begin{array}{l}\text { Strongly } \\
\text { Disagree }\end{array}$ \\
\hline & & $\mathbf{N}$ & $\mathbf{N}$ & $\mathbf{N}$ & $\mathbf{N}$ & $\mathbf{N}$ \\
\hline 3 & $\begin{array}{l}\text { The institute of my workplace provides } \\
\text { several facilities to keep the continuity of } \\
\text { the teaching and learning process via } \\
\text { online learning during the COVID-19 } \\
\text { pandemic. }\end{array}$ & $\begin{array}{c}4 \\
(80 \%)\end{array}$ & $\begin{array}{c}1 \\
(20 \%)\end{array}$ & $\begin{array}{c}- \\
(0 \%)\end{array}$ & $\begin{array}{c}- \\
(0 \%)\end{array}$ & $\begin{array}{c}- \\
(0 \%)\end{array}$ \\
\hline 5 & I am able to utilize the provided facilities. & $\begin{array}{c}4 \\
(80 \%)\end{array}$ & $\begin{array}{c}1 \\
(20 \%)\end{array}$ & $\begin{array}{c}- \\
(0 \%)\end{array}$ & $(0 \%)$ & $(0 \%)$ \\
\hline 8 & $\begin{array}{l}\text { I am able to use various applications and } \\
\text { social media to interact with my students } \\
\text { during the COVID-19 pandemic. }\end{array}$ & $\begin{array}{c}3 \\
(60 \%)\end{array}$ & $\begin{array}{c}1 \\
(20 \%)\end{array}$ & $\begin{array}{c}1 \\
(20 \%)\end{array}$ & $\begin{array}{c}- \\
(0 \%)\end{array}$ & $\begin{array}{c}- \\
(0 \%)\end{array}$ \\
\hline 11 & $\begin{array}{l}\text { I choose to use a specific application for } \\
\text { teaching because of its convenience. }\end{array}$ & $\begin{array}{c}3 \\
(60 \%)\end{array}$ & $\begin{array}{c}2 \\
(40 \%)\end{array}$ & $\begin{array}{c}- \\
(0 \%)\end{array}$ & $\begin{array}{c}- \\
(0 \%)\end{array}$ & $\begin{array}{c}- \\
(0 \%)\end{array}$ \\
\hline 15 & $\begin{array}{l}\text { I face several difficulties in using the } \\
\text { application and social media for interacting } \\
\text { with my students while applying online } \\
\text { learning. }\end{array}$ & $\begin{array}{c}- \\
(0 \%)\end{array}$ & $\begin{array}{c}2 \\
(40 \%)\end{array}$ & $\begin{array}{c}- \\
(0 \%)\end{array}$ & $\begin{array}{c}2 \\
(40 \%)\end{array}$ & $\begin{array}{c}1 \\
(20 \%)\end{array}$ \\
\hline
\end{tabular}

Even though the English in-service teachers know how to use the devices and applications, a few inservice teachers are still unfamiliar with the devices or application features. A previous study mentioned that the old-aged teachers are expected to implement online learning but are unfamiliar with the current technology [26]. Moreover, internet network connection and incompatible devices used by the in-service teachers or students became one of the main problems in online learning.

In addition, the English in-service teachers chose several applications and software were easy-to-use for them and their students. These are the supporting devices, for example, WhatsApp, Google Meet, Zoom Cloud Meeting, Google Form, Google Classroom, and school e-learning.

\subsection{Technical Support during the Application of Online English Language Teaching}

According to the findings of this result, the English in-service teachers were provided with a written guideline on how to implement an online learning class (Dokumen Satu) and conducted a BIMTEK (Bimbingan Teknis).

“... ada pelatihan BIMTEK tentang gimana cara mengatasi pembelajaran jarak jauh atau PJJ ... Kalau kuota ada, bulan kemarin ada, kalau bulan ini tidak tau tergantung atasan, tergantung pihak KEMENAG. Kalau materi belajar sebenarnya itu sudah sekaligus sama yang di BIMTEK kemarin, cara penggunaan aplikasi dan sebagainya, disitu materi belajarnya sudah ada. (English version: ... there is BIMTEK about how to resolve distance learning ... For the internet data package, we got it last month, but we do not know will we get it again or not, it depends on KEMENAG. For teaching materials, it is already given during the BIMTEK, guide on using the application and software, it is already available for the in-service teachers.)" (Participant AR)

"MAN 4 Banjar mempunyai Dokumen Satu untuk panduan pembelajaran pada masa pandemik. (English version: MAN 4 Banjar has Dokumen Satu for teaching and learning guidance during pandemic.)" (Participant H)

The problems came from hardware and software usage, and luckily, the English in-service teachers facilitated with a borrowable laptop and internet data package from a local provider $[11,21]$. This explained in the interview:

"Kalau alat komunikasi baru tidak ada, cuma yang ada itu kuotanya ada dari Telkomsel kemarin sekitar $10 \mathrm{~GB}$ kalau tidak salah, baru satu kali. (English version: For new communication device, we did not get any, but we got around 10 gigabytes of internet data package from Telkomsel if I am not mistaken, only once.)" (Participant MZ) 
“Ada, kuota internet berdasarkan acuannya dari questionnaire, the researcher found three main problems

Table 4. Questionnaire Answers about Technical Support during the Application of Online

\begin{tabular}{|c|c|c|c|c|c|c|}
\hline \multirow{3}{*}{ Items } & \multirow{3}{*}{ Questions } & \multicolumn{5}{|c|}{ In-service Teachers' Responses } \\
\hline & & $\begin{array}{l}\text { Strongly } \\
\text { Agree }\end{array}$ & Agree & Neutral & Disagree & $\begin{array}{l}\text { Strongly } \\
\text { Disagree }\end{array}$ \\
\hline & & $\mathbf{N}$ & $\mathbf{N}$ & $\mathbf{N}$ & $\mathbf{N}$ & $\mathbf{N}$ \\
\hline 2 & $\begin{array}{l}\text { I have been guided on how to implement } \\
\text { online learning. }\end{array}$ & $\begin{array}{c}3 \\
(60 \%)\end{array}$ & $\begin{array}{c}2 \\
(40 \%)\end{array}$ & $\begin{array}{c}- \\
(0 \%)\end{array}$ & $\begin{array}{c}- \\
(0 \%)\end{array}$ & $\begin{array}{c}- \\
(0 \%)\end{array}$ \\
\hline 4 & $\begin{array}{l}\text { I am able to apply online learning based on } \\
\text { the given guidance. }\end{array}$ & $\begin{array}{c}4 \\
(80 \%)\end{array}$ & $\begin{array}{c}1 \\
(20 \%)\end{array}$ & $\begin{array}{c}- \\
(0 \%)\end{array}$ & $\begin{array}{c}- \\
(0 \%)\end{array}$ & $\begin{array}{c}- \\
(0 \%)\end{array}$ \\
\hline 7 & $\begin{array}{l}\text { I am able to operate the device that I use } \\
\text { during the application of online learning in } \\
\text { the COVID-19 pandemic. }\end{array}$ & $\begin{array}{c}4 \\
(80 \%)\end{array}$ & $\begin{array}{c}1 \\
(20 \%)\end{array}$ & $\begin{array}{c}- \\
(0 \%)\end{array}$ & $\begin{array}{c}- \\
(0 \%)\end{array}$ & $\begin{array}{c}- \\
(0 \%)\end{array}$ \\
\hline 9 & I have a stable internet connection. & $\begin{array}{c}4 \\
(80 \%)\end{array}$ & $\begin{array}{c}1 \\
(20 \%) \\
\end{array}$ & $\begin{array}{c}- \\
(0 \%) \\
\end{array}$ & $\begin{array}{c}- \\
(0 \%)\end{array}$ & $\begin{array}{c}- \\
(0 \%) \\
\end{array}$ \\
\hline 16 & $\begin{array}{l}\text { I face several difficulties in operating my } \\
\text { devices during the application of online } \\
\text { learning in the COVID-19 pandemic. }\end{array}$ & $\begin{array}{c}- \\
(0 \%)\end{array}$ & $\begin{array}{c}1 \\
(20 \%)\end{array}$ & $\begin{array}{c}- \\
(0 \%)\end{array}$ & $\begin{array}{c}3 \\
(60 \%)\end{array}$ & $\begin{array}{c}1 \\
(20 \%)\end{array}$ \\
\hline
\end{tabular}

dana BOS ... Untuk alat komunikasi, ada yang memang dipinjamkan oleh sekolah (untuk guru dan siswa). (English version: There is, internet data package from Dana BOS ... For communication devices, the school lends it for the in-service teachers and students.)" (Participant H)

"Kalau perangkat baru, tidak. Kalau kuota, iya. (English version: We did not get any new device, we got internet data package instead.)" (Participant F)

"... WAKAMAD sudah membuatkan jadwal pembelajaran yang khusus pandemi, beda dari saat normal ... Kita kemaren diberi (kuota internet), ada beberapa provider yang memang menawarkan bantuan dukungan mereka terhadap pembelajaran di MAN 4 Banjar. (English version: ... WAKAMAD has made a special schedule for the pandemic situation, it is different from the normal one ... We got internet data package yesterday, there are a few internet providers which offering their support to MAN 4 Banjar to keep the continuity of teaching and learning process during the pandemic.)"

\section{(Participant BR)}

In the questionnaire answer also showed that the English in-service teachers have a good internet network connection to support online English language teaching.

\section{CONCLUSION}

After researching the problems that English inservice teachers faced during the application of online learning in COVID-19 pandemic times and analyzing the research data obtained from interview and that bother the English in-service teachers of MAN 4 Banjar.

The first problem is the problems in online English language teaching. The English in-service teachers' problem during the application of online learning related to students' behaviour. In this case, (1) the students who are slow in giving feedback, (2) less interaction between students and the in-service teachers, and (3) students who come late to the class were the main problems in this study. In addition, indirect teaching style through various software and applications was more difficult to attend. Finally, the in-service teachers' adaptability to the current lesson plan also affected online English language teaching.

In the problems in using software and application, the researcher found that bad internet connection, errors, and features mostly disrupted the process of online English language teaching in MAN 4 Banjar. The problems are mentioned: (1) written interaction in WhatsApp, (2) need to accept every student's request manually when using Google Meet, (3) annoying time reminder in Zoom Cloud Meeting, and (4) errors in uploading materials in school e-learning.

During the online learning application in MAN 4 Banjar, problems also arose from the students' side. These students' problems are: (1) an unstable internet connection, (2) disconnected from the class, (3) late to join the classes, (4) are out of internet data package, (5) late and slow on giving response to the in-service teachers, (6) late on collecting assignments, and (7) incompatible devices making the online English language teaching process slow. 


\section{AUTHORS' CONTRIBUTION}

Author 1 and 2 contributed to the research design, data collection, and data analysis. Author 3 and 4 were responsible for enriching literature and sharpening the data analysis, while Author 5 contributed to the writing format of this article.

\section{ACKNOWLEDGMENTS}

The researchers would like to thank some people who have been supporting the researcher and involved during this research process. In particular, the researchers would like to acknowledge the participants from MAN 4 Banjar for their willingness to participate in this study.

\section{REFERENCES}

[1] M. Adnan, K. Anwar, Online learning amid the COVID-19 pandemic: Students' perspectives, in: Proceedings of Journal of Pedagogical Sociology and Psychology, vol. 2, 2020, pp. 45-51.

[2] A. I. Alrawashdeh, N. N. Al-zayed, Difficulties that English in-service teachers encounter while teaching listening comprehension and their attitudes towards them, in: Proceedings of English Language Teaching, vol. 10, 2017, pp. 167-178.

[3] I. Anas, A. Musdariah, Being an e-teacher: Preparing the ESL teacher to teach English with technology, in: Proceedings Journal of English Language Teaching and Linguistics, vol. 3, 2018, pp. 41-45.

[4] B. Becta. What the research says about using ICT in Geography, Conventry, Becta, 2004.

[5] Coronavirus disease 2019 (COVID-19) pandemic: increased transmission in the EU/EEA and the UK - seventh update, Stockholm: ECDC; 2020.

[6] S. Dhawan, Online learning: A panacea in the time of COVID-19 crisis. In: Proceedings of Journal of Educational Technology System, vol. 49, 2020, pp. 5-22.

[7] I. Dhull, M. S. Sakshi, Online learning, in: Proceedings of International Education \& Research Journal, vol. 3 ,2017, pp. 32-34.

[8] A. Erarslan, A. Arslan, A. Online learning experiences of university students in ELT and the effects of online learning on their learning practices, in: Proceedings of Language and Technology, vol. 2, 2019, pp. 44-58.

[9] M. Fitriah, M. (May, 8th 2020). Liputan6. OPINI: Transformasi Media Pembelajaran pada Masa Pandemi COVID-19 [web page]. Retrieved from https://m.liputan6.com/citizen6/read/4248063/opini -transformasi-media-pembelajaran-pada-masapandemi-covid-19

[10] F. D. Gennaro, D. Pizzol, C. Marrota, M, Antunes, V. Racalbuto, N. Veronese, L. Smith, Coronavirus disease (COVID-19) current status and future perspectives: A narrative review, in: Proceedings of International Journal of Environment Research and Public Health, vol. 17, 2020, pp. 1-11.

[11] S. Ghavifekr, T. Kunjappan, L. Ramasamy, L., \& A. Anthony, Teaching and learning with ICT tools: Issues and challenges from teachers' perceptions, in: Proceedings of Malaysian Online Journal of Educational Technology, vol. 4, 2016, pp. 38-57.

[12] R. Hamid, I. Sentryo, S. Hasan, Online learning and its problems in the COVID-19 emergency period, in: Proceedings of Jurnal Prima Edukasia, vol. 8, 2020, pp. 86-95.

[13] A. Haris, (July, 20th 2020). AKURAT.co. Beberapa Permasalahan Anak yang Terjadi Saat Belajar Online di Masa Pandemi [web page]. Retrieved from https://akurat.co/id-1169753-readbeberapa-permasalahan-anak-yang-terjadi-saatbelajar-online-di-masa-pandemi

[14] L. D. Herliandry, M.E. Nurhasanah, Suban, H. Kuswanto, Pembelajaran pada masa pandemik COVID-19, in: Proceedings of Jurnal Teknologi Pendidikan, 22, 2020, pp. 65-70.

[15] A. I. Khajloo, Problems in teaching and learning English for students, in: Proceedings of International Journal of Engineering Research and Development, vol. 7, 2013, pp. 56-58.

[16] P. K. Law, COVID-19 pandemic: Its origin, implications and treatments, in: Proceedings of Open Journal of Regenerative Medicine, vol. 9, 2020, pp. 43-64.

[17] L. Mishra, T. Gupta, A. Shree, Online teachinglearning in higher education during lockdown period of COVID-19 pandemic, in: Proceedings of International Journal of Educational Research Open, 2020.

[18] M.G. Moore,Theory of transactional distance, In: D. Keegan (Ed.), Theoretical principles of distance education, New York, Routledge, 1993.

[19] Nasrullah, Pre-service and in-service English teachers' outlook in the use of online learning, in: Proceedings of The 5th UAD TEFL International Conference, 2019, pp. 54-61.

[20] S. Noom-ura, English-teaching problems in Thailand and Thai teachers' professional 
development needs, in: Proceedings of English Language Teaching, vol. 6, 2013, pp. 139-147.

[21] W. J. Pelgrum, Obstacles to the integration of ICT in education: Result from a worldwide educational assessment, in: Proceedings of Computer and Education, vol. 37, 2001, pp. 163-178.

[22] A. Pragholapati, COVID-19 Impact on Students, 2020.

[23] A. D. Primamukti, M. Farozin. Utilization of interactive multimedia to improve learning interest and learning achievement of child. Jurnal Prima Edukasia, vol. 6, 2018, pp. 111-117.

[24] R. Rasmitadila, R. Aliyyah, R. Rachmadtullah, A. Samsudin, E. Syaodih, M. Nurtanto, A. R. S. Tambunan, The perceptions of primary school teachers of online learning during the COVID-19 pandemic period: A case study in Indonesia, in: Proceedings of Journal of Ethnic and Cultural Studies, vol. 7, 2020, pp. 90-109.

[25] E. Rosalina, Nasrullah, E. P. Elyani, Teacher's challenges towards online learning in pandemic era, in: Proceedings of LET: Linguistics, Literature and English Teaching Journal, vol. 10, 2020, 7188.

[26] A. Sharma, A (2020, June 10), COVID-19 lockdown lessons and the need to reconsider draft new education policy. https://thewire.in/education/covid-19-lockdownlessons-and-theneed-to-reconsider-draft-neweducation-policy

[27] P. Sharma, Role of interactive multimedia for enhancing students' achievement and retention. International Women Online Journal of Distance Education, vol. 2, 2013, pp. 12-22.

[28] L. Sun, Y. Tang, W. Zuo, Coronavirus pushes education online, in: Proceedings of Nature Materials, vol. 19, 2020, pp. 687

[29] N. Yusnilita, The impact of online learning: Students' view, in: Proceedings of ETERNAL (English Teaching Journal), vol. 11, 2020, pp. 5761. 